
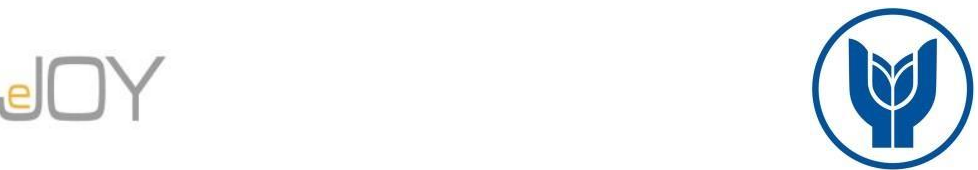

Gaberli, Ü., Akdeniz, C., Eti, H. S. / Journal of Yasar University, 2021, 16/63, 1150-1163

\title{
Does the Value of Currency Affect the Numbers of International Inbound Tourists to Turkey?
}

\section{Paranın Değeri Türkiye’ye Gelen Uluslararası Turist Sayılarını Etkiliyor Mu?}

Ümit GABERLİ, Siirt University, Turkey, umit.gaberli@siirt.edu.tr

Orcid No: 0000-0003-0097-174X

Coşkun AKDENiZ, Tekirdağ Namık Kemal University, Turkey, cakdeniz@nku.edu.tr

Orcid No: 0000-0002-3973-754X

Hasan Selçuk ETİ, Tekirdağ Namık Kemal University, Turkey, hseti@nku.edu.tr

Orcid No: 0000-0002-3792-697X

\begin{abstract}
This study examined the effect of the value of the currency on international inbound tourist numbers to Turkey from Germany and Russia, which are the top two tourist generating countries for Turkey. Two different Turkish Lira regimes are investigated with Threshold Vector Autoregressive (Threshold-VAR) models, using the real broad effective exchange rate for Turkey as a threshold variable. The endogenous variables vectors are the macroeconomic variables of the tourist origin countries: the real broad effective exchange rate, consumer price index ratio (proxying for the price level), and total industry production (proxying for income level) for Germany and Russia. Because of data constraints, the estimated Threshold-VAR models for Germany and Russia covered different periods in 1997:01-2020:05 and 2000:01-2020:05, respectively. The key finding for both policymakers and tourism researchers is that when travels become cheaper in the Turkish Lira, this does not always attract more foreign tourists to Turkey.
\end{abstract}

Keywords: International Inbound Tourist, Value of Currency, Threshold-VAR Model

JEL Classification: C32, E44, Z30

Öz: Bu çalışmada, Türkiye'ye en çok turist gönderen ilk iki ülke olan Almanya ve Rusya'nın yerel para birimlerinin değerindeki değişimin bu ülkelerden Türkiye’ye gelen turist saylları üzerindeki etkisi incelenmiştir. Bu etki, Türkiye'nin reel efektif döviz kurunun eşik değişken olarak kullanıldığı Eşik Vektör Otoregresif (Eşik-VAR) modeli ile iki farklı Türk Lirası rejimi altında incelenmiştir. Içsel değişkenlerin vektörleri, turist menşeli ülkelerin makroekonomik değişkenlerinden oluşmaktadır: Almanya ve Rusya için reel efektif döviz kuru, tüketici fiyat endeksi oranı (fiyat düzeyini temsilen) ve toplam sanayi üretimi (gelir düzeyini temsilen). Almanya ve Rusya için tahmin edilen eşik modelleri, veri kısıtı nedeniyle sirasıyla 1997:01-2020:05 ve 2000:01-2020:05 dönemlerini kapsamaktadır. Hem politika yapıcılar hem de turizm araştırmacıları için temel bulgu, seyahatler Türk Lirası açısından ucuzladığında, bunun her zaman Türkiye'ye daha fazla yabancı turist çekmemesidir.

Anahtar Kelimeler: Uluslararası Gelen Turist, Para Biriminin Değeri, Eşik-VAR Modeli

JEL Sinıflandirmasi C32, E44, Z30

\section{Introduction}

Many factors contribute to an increase in tourism demand for a particular region or country. The most important ones are income, relative tourism prices, and transportation costs (Crouch 1994, 1995; Lim 1997, 1999). While considering these critical dynamics, it is critical to distinguish between domestic and international tourism. The exchange rate is the most important variable in international tourism because visitors will undoubtedly gain more purchasing power if the value of their home currency is higher than that of the country to be 
planned to visit. This occurs when the foreign tourist's domestic currency appreciates or the currency of the visited country depreciates. When both of these events occur at the same time, the tourist's purchasing power increases even more. Thus, the relative affordability of the destination country is a fundamental reason for tourist preferences, as the relative depreciation of the local currency will boost the number of foreign tourists visiting that country. However, empirical evidence is required to verify this seemingly valid theory. As a result, this research focuses on the impact of currency fluctuations on international tourism. Activities that bring in foreign currency, with tourism being one of the leading industries in this regard, are critical for economies depending upon short term capital inflows. Furthermore, as the global growth rate has slowed in recent decades, tourism's contribution to economic growth cannot be underestimated. For example, in Dominica and Malta, travel and tourism sector is accounted for 22.3 percent and 11.7 percent of GDP in 2019, respectively (World Data Atlas, 2021).

Similarly, in Turkey, tourism has also contributed to inward foreign currency flows and economic growth. Although direct travel and tourism only contributed 3\% to GDP growth in 2019 due to the coronavirus pandemic, the average contribution for 2010-2019 was around 6\% (World Data Atlas, 2021). The 2000s have witnessed a relative boom in tourism, as seen by the increasing number of tourists visiting Turkey, particularly between 2002 and 2013 (see Figure 1). Although the number fell in 2013 due to socio-political reasons, it has increased again since 2016.

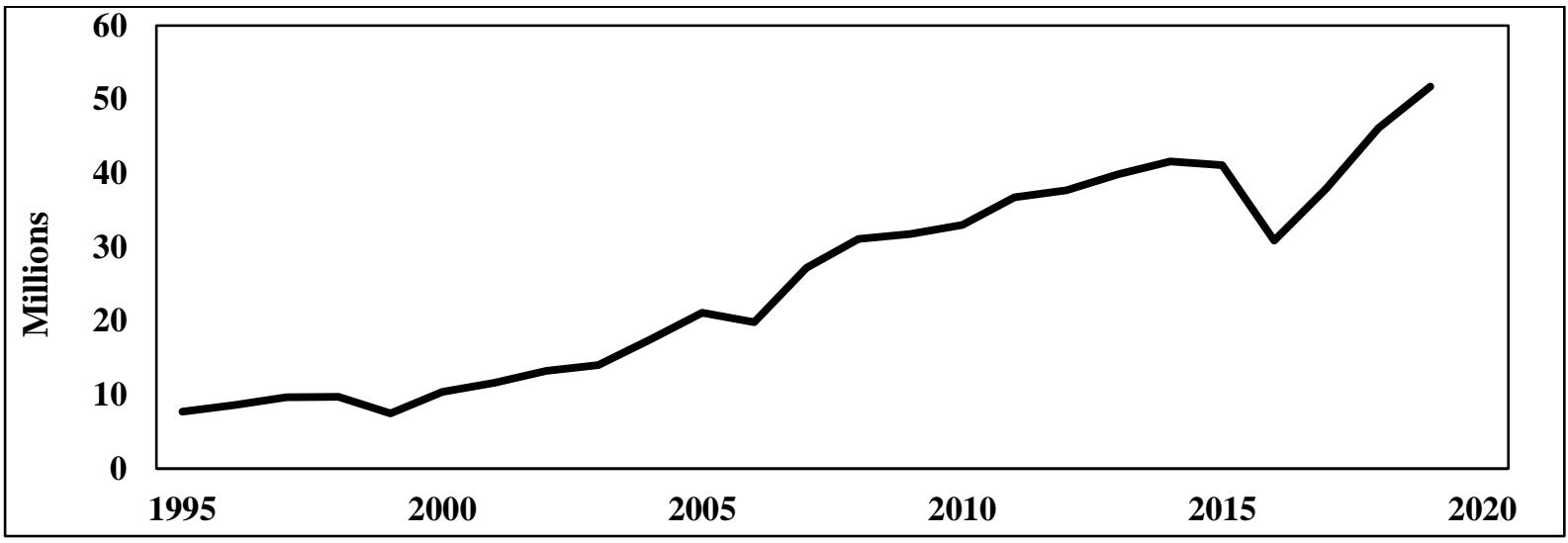

Figure 1. Trends in the Number of International Tourist Arrivals in Turkey (1995-2019)

\section{Data Source: World Bank (2021).}

Turkey has considerable tourist potential but has frequently experienced currency problems as a result of excessive outflows or insufficient short-term capital inflows. This study examines the effect of the value of money on international inbound tourist numbers to Turkey from 
Germany and Russia, which are the top two tourist generating countries for Turkey with the Threshold Autoregressive Vector (Threshold-VAR) model. Threshold-VAR models for Germany and Russia covered different periods in 1997:01-2020:05 and 2000:01-2020:05, respectively. These countries were chosen because they were the top two sources of tourist flows to Turkey between 2000 and 2019, accounting for 27\% of total foreign tourist visitors.

The following section reviews previous empirical studies of international tourist demand. Section 3 presents the dataset and variables and explains the Threshold VAR methodology. Section 4 reports the empirical findings. Finally, section 5 evaluates the results, discusses limitations, and offers suggestions for policymakers and potential contributions to future studies.

\section{International Inbound Tourism Demand Studies}

Lim (1997), who provides a comprehensive review of empirical studies of inbound tourism demand, found that the most common explanatory variables in tourism demand models are income, relative tourism prices, and transportation costs, while tourist arrivals/departures or tourist spending/receipts are the common dependent variables (Lim, 1997: 839-841). These empirical studies have used various variables and samples, from small Pacific Islands to Europe, America, and Africa. In addition, some studies use specific variables depending on their scope. For instance, Murshed et al. (2020) investigated the relationship between international tourist arrivals to South Asian countries and intra-regional trade share, the destination country's percentage share of renewables in total energy consumption, and electricity consumption per capita. Provenzano (2020) investigated the migration-tourism nexus in EU-28 countries. Kumar et al. (2020) focused on tourism prices in substitute destinations for Fiji, Cook Islands, Tonga, Vanuatu, and Samoa. Zhang et al. (2021) developed an important novel decomposition ensemble methodology using monthly data to forecast tourism demand in China and Malaysia. They found that from January 2006 to February 2016, foreign tourists in China mainly came from three countries, Japan, South Korea, and Russia. In contrast, foreign tourists in Malaysia from January 1999 to June 2019 primarily came from Singapore, Indonesia, and China.

Several studies have focused on the impact of crises on tourism demand. Wang (2009), for example, examined the effect of such events on tourism demand in Taiwan, which experienced four major disasters at approximately two-year intervals: the 1997 Asian financial crisis, the September 21, 1999 earthquake, the September 11, 2001 attacks in the United States, and the Severe Acute Respiratory Syndrome (SARS) outbreak in 2003. Nguyen and Nguyen (2021) 
studied 10 ASEAN Countries (Brunei Darussalam, Cambodia, Indonesia, Lao PDR, Malaysia, Myanmar, Philippines, Singapore, Thailand, and Vietnam) using the Political Stability and Absence of Violence Index as the explanatory variable in a panel data analysis for 2000-2016, and they found that the absence of crisis increased tourism demand. Polyzos et al. (2021) investigated the relationship between terrorism and tourism demand in Egypt, based on 2,229 terrorist events that caused 3,650 fatalities and approximately 4,520 injuries between 1995 and 2018. As expected, terrorism reduced tourist arrivals in Egypt.

Most studies have examined the determinants of tourism demand from a macroeconomic perspective, particularly by using the number of percentage change in tourist arrivals as the dependent variable (Habibi, 2017; Demirel et al., 2008; Vojtko et al., 2018) while the independent variables include exchange rate, production index, rival prices, and oil prices. These studies have used the exchange rate in different ways in their models. Demirel et al. (2008) and Karimi et al. (2018), for example, defined the real exchange rate as the nominal exchange rate multiplied by the ratio of the foreign and domestic consumer price indices, whereas Jeřábek (2019) and Gozgor et al. (2017) used the reverse form of the consumer price index ratio as the real exchange rate and Dogru et al. (2017) defined the domestic and rival countries' price level ratio as a substitute price variable. The empirical models in these studies also consider the effects of income and cost on inbound tourist numbers. Income is usually based on quarterly GDP figures, while monthly GDP can be measured by the Industrial Production Index (Rünstler and Sédillot, 2003). Thus, Jeřábek (2019), Karimi et al. (2018) (as World Price), and Dogru et al. (2017) used industrial production as a proxy variable while Jeřábek (2019) used Brent crude oil prices as a proxy of cost.

Finally, empirical studies generally use data decomposition methods and linear models (Generalized Linear Model (GLM), Generalized Method of Moments (GMM) or Vector Autoregressive (VAR), and Autoregressive-Distributed Lag (ARDL) models). However, our study aims to contribute to the tourism literature by using nonlinear regime shift models, mainly employed in the macroeconomic literature.

\section{Data and Methodology}

This study investigated the effect of the value of the currency on total international inbound tourist numbers to Turkey. We chose the source countries according to the ranking of tourist generating countries to Turkey $\left(i n b_{t}\right)$ from the Republic of Turkey Ministry of Culture and Tourism statistics database. The two countries with the highest number of inbound tourists were Russia and Germany. Due to data constraints, we are analysed 1997:01-2020:05 and 2000:01- 
2020:05 for Germany and Russia, respectively. Our empirical models included the total number of inbound tourists from Germany and Russia and three macroeconomic variables: The real broad effective exchange rate, consumer price index ratio, and total industry production belonging to the origin countries. The exchange rate regime is essential for open economies and developing countries like Turkey. Due to exchange rate regime changes and economic crises during the examined period, we employ the real broad effective exchange for Turkey as the threshold variable. Because nominal and real exchange rates move in opposite directions, we defined Turkey's currency appreciation as the increase in the real exchange rate (Catık et al., 2015). Except for the total number of inbound tourists, all data are taken from the Federal Reserve Economic Data (FRED), while the number of tourists from Germany and Russia is obtained from the Republic of Turkey Ministry of Culture and Tourism statistics. All series showing a seasonal effect are adjusted using the Seat-Tramo method. Table 1 shows the definitions, sources, and conversions of the variables.

Table 1. Definitions, Sources, and Conversions of the Variables

\begin{tabular}{|c|c|c|}
\hline Variables & Data Sources & Conversion \\
\hline $\begin{array}{c}\text { Total number of inbound tourists } \\
\left(\text { in }_{t}\right)\end{array}$ & $\begin{array}{c}\text { Republic of Turkey } \\
\text { Ministry of Culture and } \\
\text { Tourism Border Statistics }\end{array}$ & $\begin{array}{c}\text { Seasonally adjusted for log first } \\
\text { difference }\end{array}$ \\
\hline $\begin{array}{c}\text { Real broad effective exchange rate } \\
\left(\text { rer }_{t}\right)\end{array}$ & FRED & $\begin{array}{c}\text { Seasonally adjusted for log first } \\
\text { difference }\end{array}$ \\
\hline $\left.\begin{array}{c}\text { Consumer price index ratio } \\
(c p i \text { ratio }\end{array}\right)$ & FRED & $\begin{array}{c}\text { First difference of the seasonally } \\
\text { adjusted ratio of the consumer price } \\
\text { indexes }\end{array}$ \\
\hline $\begin{array}{c}\text { Total industry production }\left(\text { ip }_{t}\right) \\
\text { Threshold variable: real broad effective } \\
\text { exchange rate }\left(\text { reer_tur }_{t}\right)\end{array}$ & FRED & $\begin{array}{c}\text { Seasonally adjusted for log first } \\
\text { difference }\end{array}$ \\
\hline
\end{tabular}

As Table 1 shows, total industry production of origin countries $\left(i p_{t}\right)$, the consumer price indexes ratios (tourist originating country/Turkey) (cpi_ratio $o_{t}$ ), and the real broad effective exchange rates for the origin countries $\left(\mathrm{rer}_{t}\right)$ are measured economic activity, overall price level, and exchange rate respectively for Germany and Russia. The threshold variable, the real broad effective exchange rate for Turkey, was measured by (reer_tur $r_{t}$. For the estimated Threshold-VAR model, the relationship between the number of inbound tourists and the macroeconomic variables under different exchange rate regimes can be expressed in the following in linear form for both countries:

$$
Y_{t}^{\prime}=\left[i n b_{t} e r_{t} c p i_{t} i p_{t}\right]
$$

Following Balke (2000), the vector of the endogenous variables expressed in linear form in 
the previous equation was transformed into the following two-regime Threshold-VAR model:

$$
Y_{t}=I\left[c_{t-d} \geq \gamma\right]\left(X_{0}^{1}+\sum_{i=1}^{p} Z_{i}^{1} Y_{t-i}\right)+I\left[c_{t-d}<\gamma\right]\left(X_{0}^{2}+\sum_{i=1}^{p} Z_{i}^{2} Y_{t-i}\right)
$$

where $Y_{t}$ and $X_{t}$ represent the endogenous variable vectors and parameter matrices respectively, $\gamma$ is the optimum value of the threshold variable, illustrated by $c_{t}$, and the dummy indicator function was represented with $I[$.$] . In this model, Regime 1$ represents the appreciation of the Turkish Lira (TL) whereas Regime 2 shows the depreciation. If the threshold variable exceeds the optimal value, the economy is in Regime 1. If the threshold variable below the optimal value, then the economy is in Regime 2. The Threshold-VAR model allows for estimating regime-dependent parameters based on the threshold value and the delay parameters.

\section{Diagnostic Tests and Empirical Results}

Before estimating the Threshold-VAR model, the stationarity features of the series for both Germany and Russia are investigated using Zivot and Andrews (1992) unit root tests with a structural break. The unit root test is employed for the level and first difference of the series with three models: intercept, trend, and both terms.

Table 2. Zivot and Andrews (1992) Unit Root Test with Structural Breaks for Germany for 1997:01-2020:05

\begin{tabular}{|c|c|c|c|c|c|c|}
\hline & \multicolumn{6}{|c|}{$H_{0}:$ The series has a unit root with a structural break } \\
\hline & $\begin{array}{l}\text { Structural } \\
\text { Breaks }\end{array}$ & $\begin{array}{c}\text { Structural Break } \\
\text { Points }\end{array}$ & $\begin{array}{c}\mathrm{t} \\
\text { statistics }\end{array}$ & $\begin{array}{c}\text { Critical } \\
\text { Values for } \\
0.05\end{array}$ & Result & Decision \\
\hline \multirow{3}{*}{$\log _{-} i n b_{t}$} & Intercept & June 2016 & -1.962 & -4.800 & Accept $H_{0}$ & Non-stationary \\
\hline & Trend & November 2014 & -2.645 & -4.420 & Accept $H_{0}$ & Non-stationary \\
\hline & Both & April 2013 & -2.450 & -5.080 & Accept $H_{0}$ & Non-stationary \\
\hline \multirow{3}{*}{$\log _{-} r e r_{t}$} & Intercept & January 2010 & -3.504 & -4.800 & Accept $H_{0}$ & Non-stationary \\
\hline & Trend & October 2004 & -2.542 & -4.420 & Accept $H_{0}$ & Non-stationary \\
\hline & Both & May 2002 & -3.780 & -5.080 & Accept $H_{0}$ & Non-stationary \\
\hline \multirow{3}{*}{ cpi_ratio $_{t}$} & Intercept & October 2003 & -8.136 & -4.800 & Reject $H_{0}$ & Stationary \\
\hline & Trend & January 2017 & -7.903 & -4.420 & Reject $H_{0}$ & Stationary \\
\hline & Both & January 2017 & -7.877 & -5.080 & Reject $H_{0}$ & Stationary \\
\hline \multirow{3}{*}{$\log _{-} i p_{t}$} & Intercept & January 2005 & -1.704 & -4.800 & Accept $H_{0}$ & Non-stationary \\
\hline & Trend & December 2016 & -2.458 & -4.420 & Accept $H_{0}$ & Non-stationary \\
\hline & Both & December 2016 & -2.740 & -5.080 & Accept $H_{0}$ & Non-stationary \\
\hline \multirow{3}{*}{$\Delta \log _{-} i n b_{t}$} & Intercept & November 2016 & -13.902 & -4.800 & Reject $H_{0}$ & Stationary \\
\hline & Trend & December 2016 & -14.654 & -4.420 & Reject $H_{0}$ & Stationary \\
\hline & Both & December 2016 & -15.002 & -5.080 & Reject $H_{0}$ & Stationary \\
\hline \multirow{3}{*}{$\Delta \log _{-} r e r_{t}$} & Intercept & November 2000 & -11.721 & -4.800 & Reject $H_{0}$ & Stationary \\
\hline & Trend & July 2002 & -11.455 & -4.420 & Reject $H_{0}$ & Stationary \\
\hline & Both & November 2000 & -11.944 & -5.080 & Reject $H_{0}$ & Stationary \\
\hline \multirow{2}{*}{$\Delta c p i \_r a t i o_{t}$} & Intercept & May 2001 & -11.396 & -4.800 & Reject $H_{0}$ & Stationary \\
\hline & Trend & November 2016 & -10.108 & -4.420 & Reject $H_{0}$ & Stationary \\
\hline
\end{tabular}




\begin{tabular}{|c|c|c|c|c|c|c|}
\hline & Both & November 2016 & -10.102 & -5.080 & Reject $H_{0}$ & Stationary \\
\hline \multirow{3}{*}{$\Delta \log _{-} i p_{t}$} & Intercept & May 2009 & -7.630 & -4.800 & Reject $H_{0}$ & Stationary \\
\cline { 2 - 7 } & Trend & December 2016 & -7.691 & -4.420 & Reject $H_{0}$ & Stationary \\
\cline { 2 - 7 } & Both & December 2016 & -7.924 & -5.080 & Reject $H_{0}$ & Stationary \\
\hline
\end{tabular}

Table 2 shows the unit root test with one structural break for Germany for 1997:01-2020:05. Only the cpi_ratio variable is stationary at the level, whereas the first differences of all series are stationary at least the 5\% confidence level. The first difference of Germany's total number of inbound tourists series has two different structural breakpoints: November and December 2016 (see Table 2). These points indicate approximately the ending of a downward trend which begins in July 2016.

Table 3. Zivot and Andrews (1992) Unit Root Test with Structural Breaks for Russia for 2000:01-2020:05

\begin{tabular}{|c|c|c|c|c|c|c|}
\hline & \multicolumn{6}{|c|}{$H_{0}:$ The series has a unit root with a structural break } \\
\hline & $\begin{array}{l}\text { Structural } \\
\text { Breaks }\end{array}$ & $\begin{array}{l}\text { Structural Break } \\
\text { Points }\end{array}$ & $\stackrel{\mathrm{t}}{\text { statistics }}$ & $\begin{array}{l}\text { Critical } \\
\text { Values } \\
\text { for } 0.05\end{array}$ & Result & Decision \\
\hline \multirow{3}{*}{$\log _{-} i n b_{t}$} & Intercept & December 2015 & -3.991 & -4.800 & Accept $H_{0}$ & Non-stationary \\
\hline & Trend & May 2010 & -3.822 & -4.420 & Accept $H_{0}$ & Non-stationary \\
\hline & Both & May 2008 & -3.802 & -5.080 & Accept $H_{0}$ & Non-stationary \\
\hline \multirow{3}{*}{$\log _{-} r e r_{t}$} & Intercept & August 2014 & -4.160 & -4.800 & Accept $H_{0}$ & Non-stationary \\
\hline & Trend & April 2010 & -3.364 & -4.420 & Accept $H_{0}$ & Non-stationary \\
\hline & Both & August 2014 & -4.106 & -5.080 & Accept $H_{0}$ & Non-stationary \\
\hline \multirow{3}{*}{ cpi_ratio $_{t}$} & Intercept & August 2017 & -4.806 & -4.800 & Reject $H_{0}$ & Stationary \\
\hline & Trend & January 2016 & -4.976 & -4.420 & Reject $H_{0}$ & Stationary \\
\hline & Both & November 2014 & -5.018 & -5.080 & Accept $H_{0}$ & Non-Stationary \\
\hline \multirow{3}{*}{$\log _{-} i p_{t}$} & Intercept & July 2003 & -2.771 & -4.800 & Accept $H_{0}$ & Non-stationary \\
\hline & Trend & March 2005 & -3.973 & -4.420 & Accept $H_{0}$ & Non-stationary \\
\hline & Both & October 2008 & -5.702 & -5.080 & Reject $H_{0}$ & Stationary \\
\hline \multirow{3}{*}{$\Delta \log _{-} i n b_{t}$} & Intercept & October 2016 & -12.185 & -4.800 & Reject $H_{0}$ & Stationary \\
\hline & Trend & August 2017 & -12.229 & -4.420 & Reject $\mathrm{H}_{0}$ & Stationary \\
\hline & Both & October 2016 & -13.143 & -5.080 & Reject $\mathrm{H}_{0}$ & Stationary \\
\hline \multirow{3}{*}{$\Delta \log _{-} r e r_{t}$} & Intercept & February 2016 & -11.229 & -4.800 & Reject $\mathrm{H}_{0}$ & Stationary \\
\hline & Trend & May 2003 & -10.838 & -4.420 & Reject $\mathrm{H}_{0}$ & Stationary \\
\hline & Both & March 2016 & -11.408 & -5.080 & Reject $\mathrm{H}_{0}$ & Stationary \\
\hline \multirow{3}{*}{$\Delta c p i \_r a t i o_{t}$} & Intercept & July 2003 & -4.632 & -4.800 & Accept $H_{0}$ & Non-stationary \\
\hline & Trend & November 2003 & -5.586 & -4.420 & Reject $H_{0}$ & Stationary \\
\hline & Both & April 2004 & -5.456 & -5.080 & Reject $\mathrm{H}_{0}$ & Stationary \\
\hline \multirow{3}{*}{$\Delta \log _{-} i p_{t}$} & Intercept & February 2008 & -9.277 & -4.800 & Reject $H_{0}$ & Stationary \\
\hline & Trend & May 2003 & -9.263 & -4.420 & Reject $H_{0}$ & Stationary \\
\hline & Both & June 2003 & -9.364 & -5.080 & Reject $H_{0}$ & Stationary \\
\hline
\end{tabular}

Table 3 presents the unit root test results with one structural break for Russia for 2000:012020:05. The first differences of all series have no unit root for at least the 5\% confidence level except for the consumer price index ratio. This series has a unit root with the constant term 
model. However, the time trend model and the model that includes both stochastics terms are stationary. We ignored the constant term model and focused on the results containing both terms. The number of inbound tourists from Russia had two different structural breakpoints: October 2016 and August 2017 (see Table 3).

Before estimating equation (2), the existence of threshold nonlinearity is investigated using the nonlinear threshold test developed by Tsay (1998). The $C(d)$ statistic has been computed over the trimmed interval of the threshold variable. The starting point of the recursive estimation $\left(m_{0}\right)$ and the delay parameters $(d)$ are presented in Table 4 . The null hypothesis of linearity is rejected at the $1 \%$ significance level for the Threshold-VAR models for Germany and Russia. The optimum delay parameter of the Threshold-VAR model is one for both models. The $C(d)$ test also computed the optimal value of the threshold variables based on the minimum Akaike Information Criteria (AIC). Using the real broad effective exchange rate for Turkey as the threshold variable in the German and Russian case, we found that the optimal threshold values are 71.15 and 75.25 for the estimated Threshold-VAR models for Germany and Russia, respectively.

Table 4. $C(d)$ Threshold Nonlinearity Test Results for Germany and Russia

\begin{tabular}{|c|c|c|c|c|c|c|c|}
\hline \multicolumn{4}{|c|}{ Germany } & \multicolumn{4}{|c|}{ Russia } \\
\hline$d$ & $m_{0}$ & $C_{d}$ & $p$ value & $d$ & $m_{0}$ & $C_{d}$ & $p$ value \\
\hline 1 & 50 & 282.11 & 0.00 & 1 & 50 & 217.43 & 0.00 \\
\hline 1 & 100 & 276.14 & 0.00 & 1 & 100 & 156.10 & 0.00 \\
\hline 2 & 50 & 262.07 & 0.00 & 2 & 50 & 185.42 & 0.00 \\
\hline 2 & 100 & 278.68 & 0.00 & 2 & 100 & 183.16 & 0.00 \\
\hline 3 & 50 & 263.88 & 0.00 & 3 & 50 & 172.14 & 0.00 \\
\hline 3 & 100 & 301.39 & 0.00 & 3 & 100 & 185.55 & 0.00 \\
\hline 4 & 50 & 252.99 & 0.00 & 4 & 50 & 171.47 & 0.00 \\
\hline 4 & 100 & 295.20 & 0.00 & 4 & 100 & 162.11 & 0.00 \\
\hline \multicolumn{4}{|c|}{$\begin{array}{c}\gamma=71.15 \\
\text { AIC: }-4411.18\end{array}$} & \multicolumn{4}{|c|}{$\begin{array}{c}\gamma=75.25 \\
\text { AIC: }-3901.37\end{array}$} \\
\hline
\end{tabular}

Figure 2 shows the high and low regimes based on the estimated Threshold-VAR models for Germany and Russia. The shaded areas represent the higher regime in which the real broad effective exchange rate for Turkey exceeded its optimum threshold values, i.e., when the TL is appreciating. Following the 2001 crisis, Turkey implemented structural reforms to alleviate the effects of this crisis. In particular, the Central Bank of the Republic of Turkey (CBRT) gained instrumental independence and adopted a floating exchange rate regime. Along with the structural reforms and the transition to inflation targeting, TL started to appreciate. Between 2002 and 2013, TL followed a relatively stable course. However, the depreciation accelerated 
with the FED's announcement in May 2013 (Ilhan and Ozdemir, 2019: 792) and the value of TL hit the bottom as a result of the currency shock in August 2018.
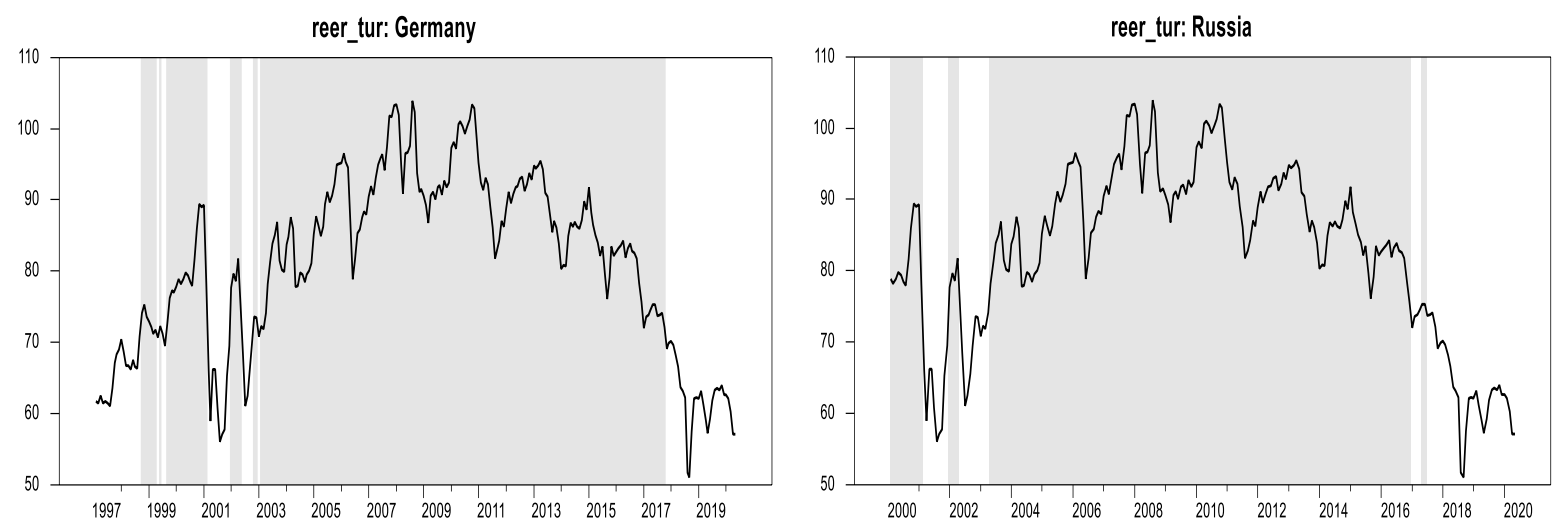

Figure 2. TL Currency Regime Classifications Based on the Threshold Variable

Figure 3 presents the responses of the total numbers of inbound tourists from Germany and Russia to the macroeconomic shocks in their economies. As Germany's local currency, the Euro, appreciated, the number of German tourists arriving in Turkey fell. Conversely, as Russia's local currency, the Rouble, appreciated, the number of Russian tourists coming to Turkey rose. However, the responses of numbers of inbound tourists to relative price ratio shocks in Germany and Russia are not as significant as production growth; in other words, income growth in those countries increased the numbers of inbound tourists to Turkey from both Germany and Russia.

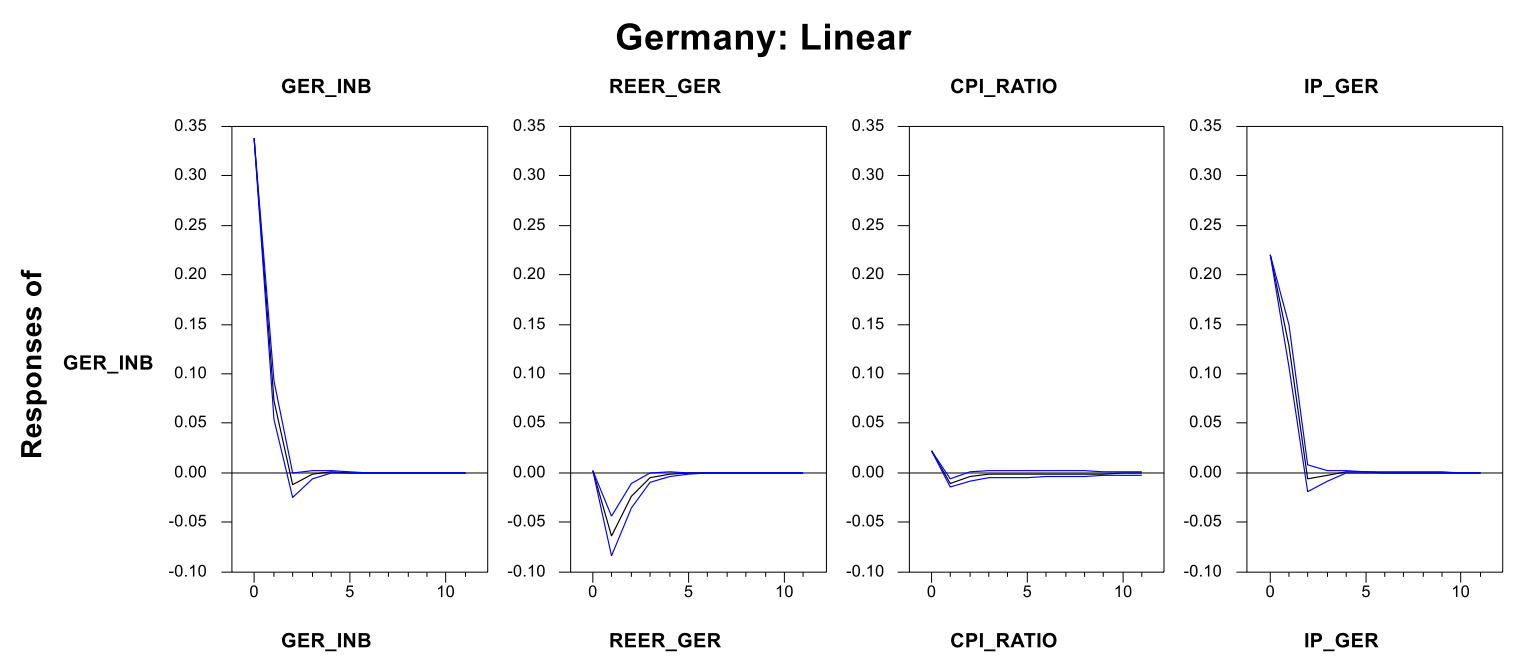




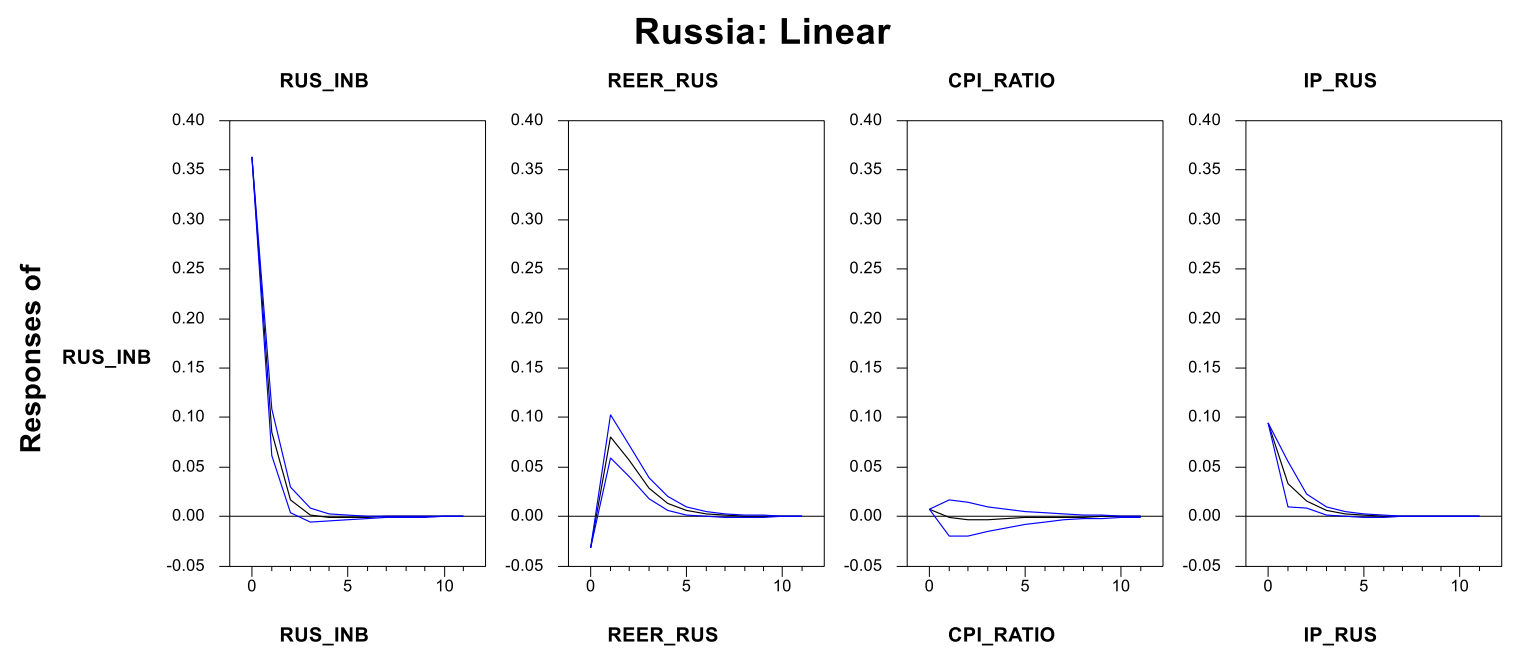

Figure 3. Linear Impulse-Response Functions for Germany and Russia

Figures 4 and 5 present the Threshold-VAR model estimations under the lower and higher regimes. Figure 4 shows that whenever the TL is worthless (under the lower regime), an increase in the Euro's value reduced the number of German tourists visiting Turkey. However, the number of tourists responding to the real effective exchange rate shocks is statistically significant and positive for Russia. That is, more Russian tourists visited Turkey whenever the Rouble's value increased. On the other hand, the number of German and Russian tourists visiting Turkey increased in line with production growth in both countries. Only relative consumer price ratio shocks are generally insignificant. In brief, all findings under the lower regime overlap with the linear VAR model results.

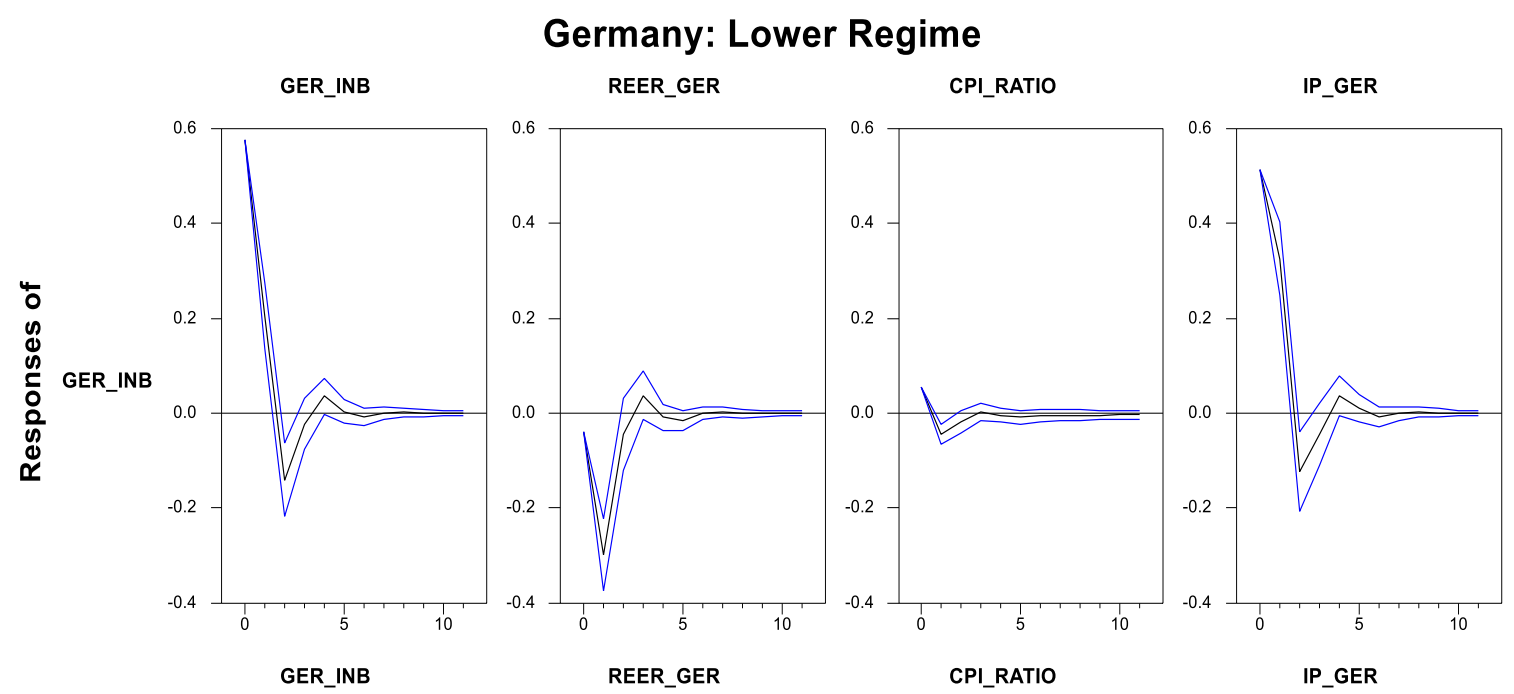




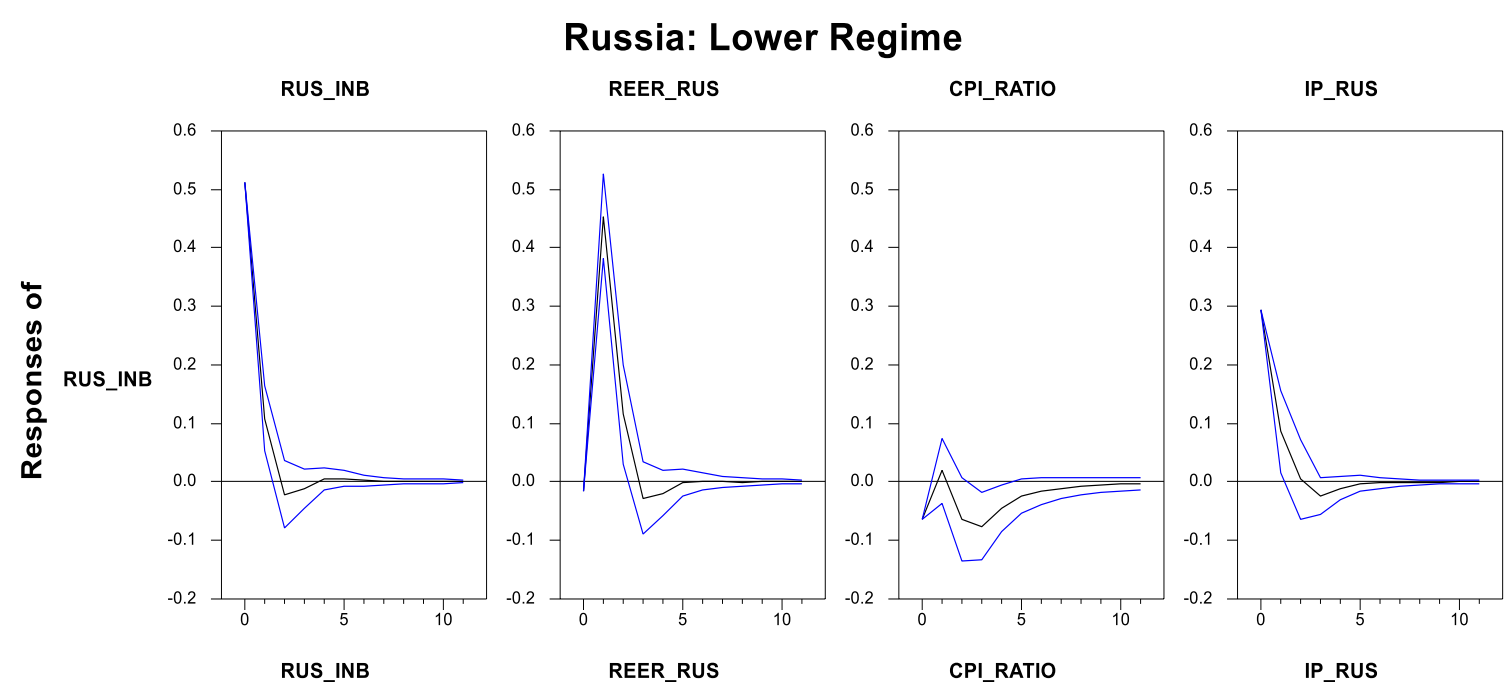

Figure 4. Impulse-Response Functions in the Lower Regime for Germany and Russia

When the TL is valuable (under the higher regime), both Germany and Russia's results differed from the linear and lower regime findings. An increase in the Euro's or Rouble's value briefly increased the number of German or Russian tourists visiting Turkey, although these responses are generally statistically insignificant. Relative price shocks in both countries have similar effects. Lastly, greater economic activity increased the number of inbound tourists to Turkey from Germany and Russia, as with the low regime results.

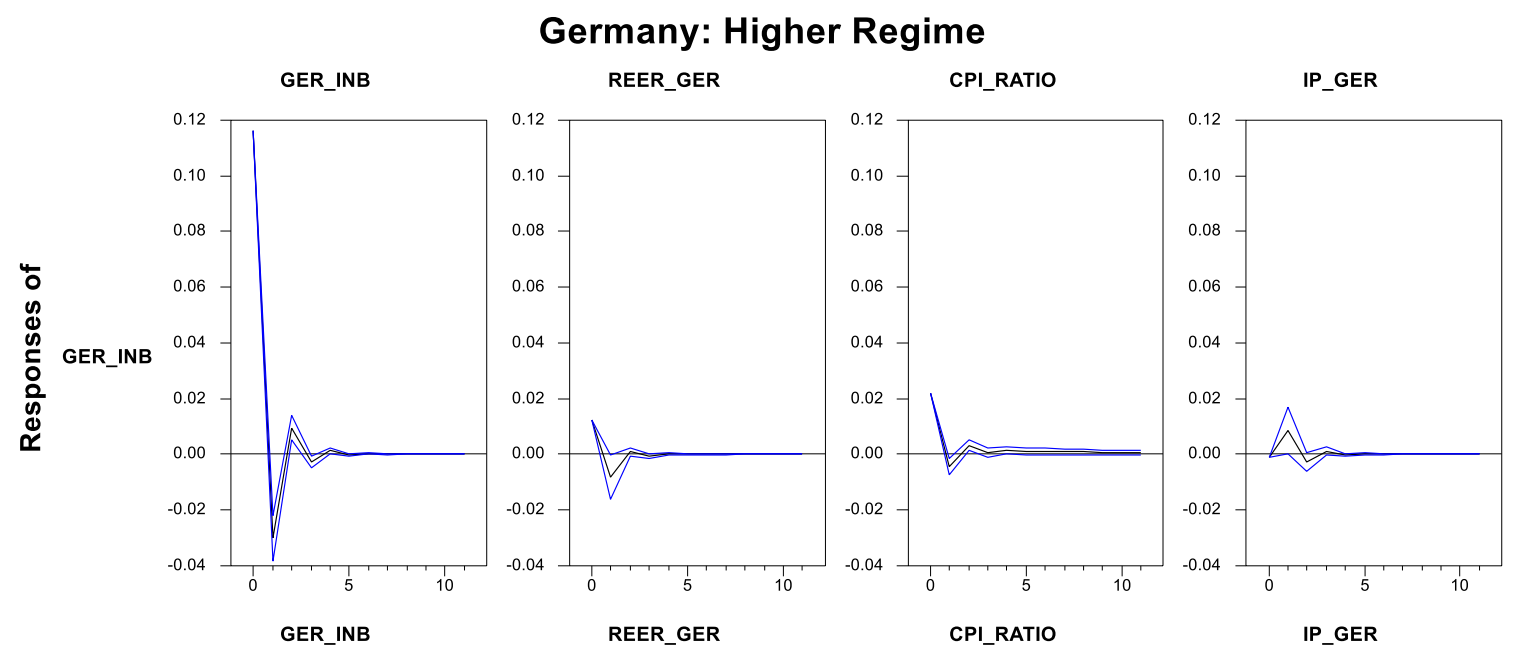




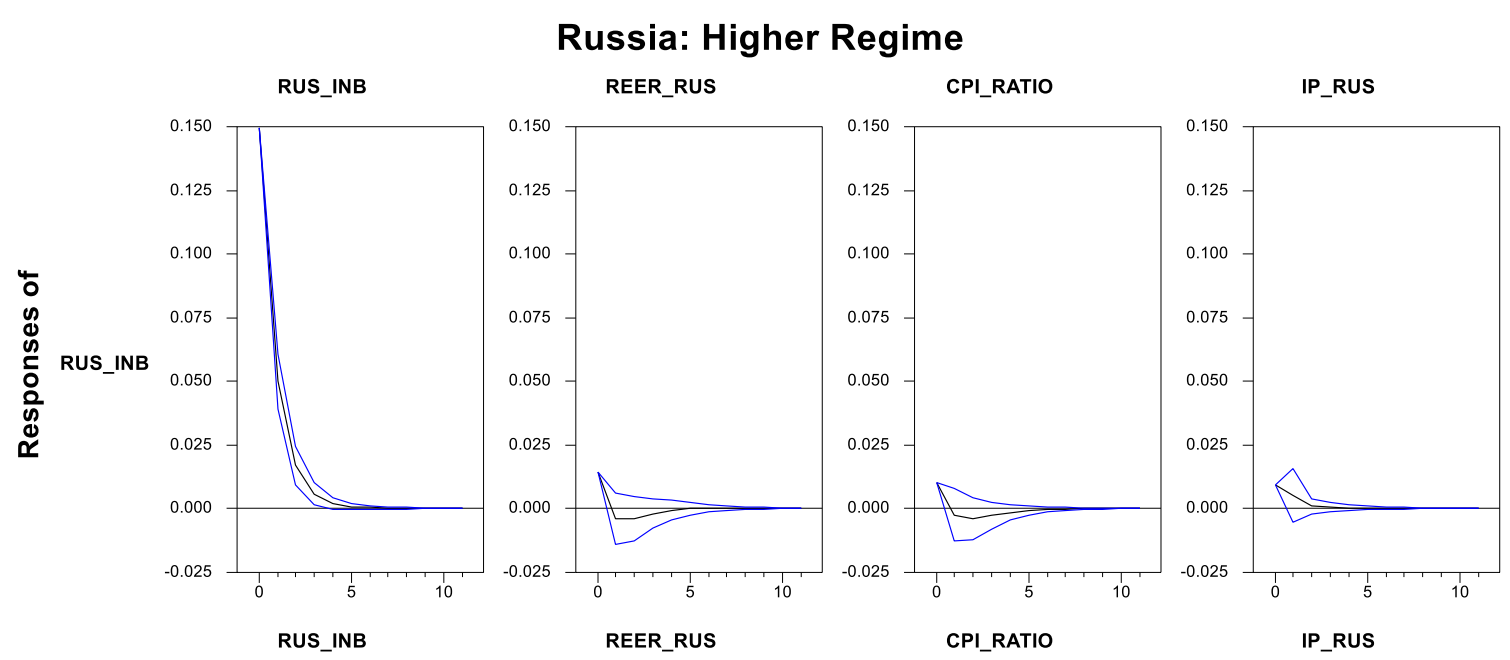

Figure 5. Impulse-Response Functions in the Higher Regime for Germany and Russia

\section{Conclusions and Discussion}

Certain destinations may become more affordable to tourists as the local currency weakens. Our analysis of the effect of currency appreciation and depreciation on international inbound tourism revealed startling results that vary by source country.

The linear model results indicate that as the Euro gains value, the number of German tourists visiting Turkey declines, while the Rouble gains value, the number of Russian tourists increases. These findings are identical in the low regime, where TL is weak. However, the responses of Russia and Germany to shocks under low regimes are more significant than those of the linear model. This means that the depreciation of the Turkish lira, combined with the appreciation of the domestic currencies of Russian and German tourists, makes Turkey even more affordable in terms of foreign currency. In short, under a regime with a relatively weak Turkish lira, the number of tourists visiting Turkey from Germany, a developed country, declines as the local German currency (Euro) appreciates.

Conversely, the number of tourists coming from Russia, a developing country, increases as the local Russian currency (Rouble) rises. These findings suggest that tourist behavior varies depending on a source country's development level responses become insignificant except for a short period. Thus, to answer the main research question motivating this study, a devalued TL does not always lead to a rise in the number of tourists visiting Turkey. Regarding total industry production $\left(i p_{t}\right)$ and the ratio of the consumer price indexes $\left(c p i\right.$ ratio $\left._{t}\right)$ variables, which are included in the analysis as control variables, increase production/revenue in source countries and increase the number of tourists visiting Turkey, regardless of whether TL appreciates or 
depreciates. Responses to price shocks in source countries are only significant for a brief period in both the linear and nonlinear models.

While our empirical findings are compared to those of previous studies, the analysis distinguishes across sample and time dimensions due to the fact that we chose the source nations based on Turkey's ranking among tourist-generating countries. Additionally, the conclusion for Germany departs from the literature in that the number of incoming tourists from the origin country fell as the national currency of the tourist-generating country appreciated. In the instance of Russia, a conclusion was reached that is consistent with the literature.

The study has two broad implications. Although this is a macro-level study, the first of them is the ability to influence the marketing strategies of travel agencies that bring tourists from Germany. Because of Turkey's relative affordability, the number of tourists from Germany declines. As a result, these agencies' plans should be based on non-price variables. Second, it has an effect on researchers in this discipline. In contrast to the literature, macroeconomic indicators from the tourist-generating country, rather than the host country, are employed to estimate tourism demand. In this regard, the study serves as a seminal resource for researchers.

The study also has two main limitations. First, we only considered the macroeconomic determinants of international tourism demand. Therefore, we ignored the microeconomic factors of international tourism. Second, the dataset was only available for a short period of time, limiting the possibility of observing different impulse-response relationships. Nonetheless, our results suggest to policymakers that converting a country into a low-cost destination through currency depreciation does not always lead to increased tourist activities. Additionally, the study provides empirical evidence for tourism research that tourist responses to economic stimuli vary according to the development level of the source countries. Finally, future research can examine the effects of non-economic factors on tourism demand, such as terrorism, political stability, and education level, using the nonlinear regime shift model technique. 


\section{REFERENCES}

Balke, N. 2000. "Credit and Economic Activity: Credit Regimes and Non- linear Propagation of Shocks", Review of Economics and Statistics, 82, 344-349.

Catık, A. N., Gök, B., \& Akseki, U. 2015. "A nonlinear investigation of the twin deficits hypothesis over the business cycle: Evidence from Turkey", Economic Systems, 39(1), 181-196.

Crouch, G. I. 1994. "The Study of International Tourism Demand: A Review of Findings", Journal of Travel Research, 33 (1), 12-23.

Crouch, G. I. 1995. "A Meta-Analysis of Tourism Demand", Annals of Tourism Research, 22 (1), 103-118.

Demirel, B., Bozdag, E. G. \& Inci, A. G. 2008. "Döviz Kurlarındaki Dalgalanmaların Gelen Turist Sayısına Etkisi; Türkiye Örneği” [The Impact Of Exchange Rates Volatility On Tourist Arrivals: A Case Study Of Turkey], Dokuz Eylül Üniversitesi Sosyal Bilimler Dergisi.

Dogru, T., Sirakaya-Turk, E. \& Crouch, G. I. 2017. "Remodeling International Tourism Demand: Old Theory and New Evidence", Tourism Management, 60 (2017), 47-55.

Gozgor, G., Demir, E. \& Bilgin, M. H. 2017. "The effects of the military in politics on the inbound tourism: evidence from Turkey", Asia Pacific Journal of Tourism Research, 22(8), 885-893.

Habibi, F. 2017. "The Determinants of Inbound Tourism to Malaysia: A Panel Data Analysis", Current Issues in Tourism, 20 (9), 909-930.

Ilhan, A. \& Ozdemir, M. 2019. "Türkiye'de Yeni Politika Bileşiminin Finansal İstikrar ve Fiyat İstikrarı Üzerindeki Etkilerine İlişkin Bir Değerlendirme”, Business and Economics Research Journal, 10(4), 789806.

Jeřábek, T. 2019. "The Effects of Selected Macroeconomic Variables on Tourism Demand for the South Moravian Region of the Czech Republic from Germany, Poland, Austria, and Slovakia", Comparative Economic Research. Central and Eastern Europe, 22 (3), 25-43.

Karimi, M. S., Khan, A. A. \& Karemelikli, H. 2018. "Asymmetric Effects of Real Exchange Rate on Inbound Tourist Arrivals in Malaysia: An Analysis of Price Rigidity", International Journal of Tourism Research, 21 (2), 150-164.

Kumar, N., Kumar, R.R., Patel, A., Shahzad, S.J.H. \& Stauvermann, P. J. 2020. "Modelling Inbound International Tourism Demand in Small Pacific Island Countries", Applied Economics, 52 (10), 1031-1047.

Lim, C. 1997. "Review of International Tourism Demand Models", Annals of Tourism Research, 24 (4), 835-849.

Lim, C. 1999. "A Meta-Analytic Review of International Tourism Demand" Journal of Travel Research, 37 (3), 273-284.

Murshed, M., Mahmood, H., Alkhateeb, T. T. Y. \& Banerjee, S. 2020. "Calibrating the Impacts of Regional Trade Integration and Renewable Energy Transition on the Sustainability of International Inbound Tourism Demand in South Asia", Sustainability, 12 (20), 8341.

Nguyen, L. P. \& Nguyen, H. T. 2021. "Factors Impacting Tourism Demand: An Analysis of 10 ASEAN Countries", Journal of Asian Finance, Economics and Business, 8 (1), 385-393.

Polyzos, S., Papadopoulou, G. \& Xesfingi, S. 2021. "Examining the link between terrorism and tourism demand: the case of Egypt", Journal of Policy Research in Tourism, Leisure and Events, DOI: 10.1080/19407963.2021.1904965

Provenzano, D. 2020. "The Migration-Tourism Nexus in the EU28", Tourism Economics, 26 (8), 1374-1393.

Rünstler, G. \& Sédillot, F. 2003. "Short-Term Estimates of Euro Area Real GDP by Means of Monthly Data", European Central Bank Working Paper Series, Working Paper No. 276.

Tsay, R. S. 1998. "Testing and Modeling Multivariate Threshold Models", Journal of the American Statistical Association, 93, 1188-1998.

Vojtko, V., Štumpf, P., Kovačić, M. \& Janeček, P. 2018. "Better Understanding of Exchange Rate Effects in Destination Marketing: Cases of the Czech Republic and Croatia", Tourism: An International Interdisciplinary Journal, 66 (4), 379-395.

Wang, YS. 2009. "The Impact of Crisis Events and Macroeconomic Activity on Taiwan's International Inbound Tourism Demand", Tourism Management, 30 (1), 75-82.

World Bank 2021. https://data.worldbank.org/indicator/ST.INT.ARVL (Accessed: 01.03.2021).

World Data Atlas 2021. https://knoema.com/atlas/topics/Tourism (Accessed: 10.03.2021).

Zhang, C., Jiang, F., Wang, S. \& Sun, S. 2021. "A New Decomposition Ensemble Approach for Tourism Demand Forecasting: Evidence from Major Source Countries in Asia-Pacific Region" International Journal of Tourism Research, 23 (2), 1-14.

Zivot, E. \& Andrews, D. W. K. 1992. "Further evidence on the great crash, the oil-price shock, and the unit-root hypothesis", Journal of Business \& Economic Statistics, Vol. 10, No.3, 251-270. 